\title{
New Demographic Evidence on Collectivization Deaths: A Rejoinder to Stephen Wheatcroft
}

Most Western scholars agree that the Soviet Union experienced a significant number of excess deaths during the 1930s which are attributable to forced collectivization from 1929 to 1932, the famine of 1933-34, Gulag forced labor, and the terror. Until comparatively recently, however, the official data required for a reliable estimate of the magnitude and incidence of these excess fatalities have been unavailable. In May 1984 I reported that new evidence had been released which shed considerable light on one aspect of this important problem: forced collectivization between 1929 and 1932. ${ }^{1}$ The evidence took two forms: a revised natality series for the 1930s, and a previously unpublished population statistic for 1933 , both provided by the distinguished Soviet demographer Boris Urlanis. ${ }^{2}$ On the basis of this information, previously published Soviet vital statistics, and 1926/27 census data, two alternative estimates of excess deaths attributable to forced collectivization were computed. ${ }^{3}$ The first, derived without adjustment from these Soviet statistics and computed using the method employed by Frank Lorimer in his classic League of Nations study, The Population of the Soviet Union: History and Prospects (1946), indicated that the Soviet Union sustained 5.8 million excess fatalities from January 1, 1929 to January 1, 1933 that were attributable to forced collectivization. The second estimate, which took into account the possibility that the official, census-based mortality rate for 1927 may have understated the real rate, yielded a lower figure, 5.1 million. These findings led me to conclude that the approximately 5 million excess deaths attributed by Murray Feshbach to "the liquidation of the kulaks and forced land collectivization in the early thirties" was well founded and broadly substantiated by Urlanis's data. ${ }^{4}$

As claimed previously, I believe this is a very powerful, if admittedly restricted, result. It does not settle the further issues of famine-related excess deaths in 1933/34 and of excess fatalities imputable to Gulag forced labor and

1. Steven Rosefielde, "Excess Collectivization Deaths 1929-1933: New Demographic Evidence," Slavic Review, 42, no. 1 (Spring 1984): 83-88. The precise dating is January 1, 1929 to January 1, 1933.

2. Wheatcroft chides me for describing Urlanis as a leading-if not the leading-Soviet demographer, but then shifts his ground and refers to him as "the grand old man of Soviet demography."

3. Rosefielde, "Excess Collectivization Deaths," tables 1 and A1, pp. 84 and 87.

4. Murray Feshbach, "The Soviet Union: Population Trends and Dilemmas," Population Bulletin, 37, no. 3 (August 1982): 7. Wheatcroft alleges that Feshbach did not attribute 5 million deaths to collectivization as cited above. He accomplishes this by ignoring the distinction drawn in my text and Feshbach's between collectivization per se 1929-32 and the famine 1933-34. See Wheatcroft, "New Demographic Evidence," and Rosefielde, "Excess Collectivization Deaths," pp. 83 and 88. There is some overlap in Feshbach's and my periodization 1932-33, but this ambiguity does not justify Wheatcroft's distortion. It should also be noted that Mace insists that the famine ended in 1933. See James Mace, "Response to Stephen Wheatcroft," Problems of Communism, 34 (MarchApril 1985): 137. 
the terror. It does not provide a single exact estimate of mortality related to excess collectivization, ${ }^{5}$ and it does not resolve uncertainties that mar the reliability of all Soviet statistics. Nonetheless, it firmly establishes that official Soviet demographic statistics support excess mortality estimates in the vicinity of 5 million people during forced collectivization between 1929 and 1932.

Stephen Wheatcroft challenges this statement. He does not contest Lorimer's estimating procedure ${ }^{6}$ or my arithmetic. Nor does he deny the authenticity of Urlanis's new evidence. ${ }^{7}$ Indeed, he not only acknowledges that Urlanis's 1933 population estimate is consistent with Lorimer's, but informs us that Urlanis personally confirmed his sympathy with Lorimer's estimate in a private interview. ${ }^{8}$ Why then does he categorically reject my results?

Wheatcroft builds his case on two substantive arguments. First he asserts that the population statistic for 1933 which I employ is contradicted by an alternative estimate on the preceding page of Urlanis's book Problemy dinamiki naseleniia SSSR, and second that official Soviet demographic statistics exaggerate excess mortality between 1929 and 1949.

The first assertion, as Wheatcroft himself intimates, is baseless. ${ }^{9}$ The population statistic I cite appears in a table comparing Gosplan's population growth projection from April 1, 1928 to April 1, 1933 with the actual populations (fakticheskie dannye) on April 1, 1928 and on an unspecified date in 1933. ${ }^{10}$ The latter statistic is marked with an asterisk indicating that it is approximate (priblizitel'no) with regard either to the true figure on April 1, 1933 or the true figure on another unspecified date, presumably January 1, 1933 in accordance with standard practice. ${ }^{11}$ The heading "fakticheskie dannye" indicates that the population statistics for 1928 and 1933 are best estimates based on available official data. ${ }^{12}$ No qualifying statements appear in either the table or the accompanying text to suggest that the population statistic for 1933 is casually derived from fragmentary unofficial data, or that the term "priblizitel' no" should be interpreted as a range rather than a point estimate.

5. Wheatcroft for rhetorical effect twists the interpretation I place on my findings by asserting that "Rosefielde is implying an accuracy within one hundred thousand." See also n. 27.

6. Wheatcroft accepts Lorimer's excess death estimates subject to various minor qualifications. Presumably he believes his estimating procedure is correct, although his comments about inflated and noninflated data suggest that he may not fully grasp Lorimer's method.

7. "Urlanis's estimate of the 1933 population level of approximately 158 million is significantly lower than the only Soviet official figures that have ever appeared." Wheatcroft, "New Demographic Evidence." Compare discussion of Gertsenzon and Shliapochnikov's 1933 population statistic of 155.1 million in n. 24.

8. Ibid., n. 9.

9. "On one page Urlanis talks about a real 1933 figure of about 160.7 million and on another of approximately 158.2 million. This is not necessarily a contradiction." Ibid.

10. "The Gosplan projection cited by Urlanis referred not to January 1, 1933 as Rosefielde claims, but to April 1, 1933." Ibid. I made no such claim. Of course the Gosplan figure is a fiveyear projection point to point April 1, 1928 to April 1, 1933. But this in no way informs us whether Urlanis's 1933 population estimate pertains precisely to April 1, 1933 or any other date.

11. Compare the original Novosel'skii and Paevskii population estimates cited by Urlanis, Problemy dinamiki naseleniia (Moscow, 1974), p. 318, and reported in "O svodnykh kharakeristikakh vosproizvodstva i perspektivykh ischisleniiakh naseleniia," Trudy demograficheskogo instituta, tom I, 1934, p. 16.

12. Wheatcroft's assertion about the unreliability of Urlanis's population statistic for 1933 is unconvincing. The fact that there was no census taken in 1931 or 1933 does not mean that other sampling procedures were not employed. 
The alternative population statistic that allegedly contradicts the one I report is derived by Wheatcroft from Urlanis's assertion that the population estimate computed by Novosel'skii and Paevskii for January 1, 1933 exceeded the true population in 1933 by roughly 7 million people. ${ }^{13}$ Wheatcroft presumes that the "true population" in 1933 refers to January $1,1933,{ }^{14}$ permitting him to infer that the actual population on April 1, 1933 was 161.4 million, ${ }^{15} 3.4$ higher than reported in Urlanis's table. ${ }^{16}$ This supposed discrepancy, however, is entirely of Wheatcroft's contriving. The preceding text indicates that the actual population to which Urlanis refers is not that of January 1, 1933, but of the end of 1933, "uzhe v moment publikatsii." 17 If Urlanis plausibly estimated a 2.7 million net population increase between January 1, 1933 and December 31, 1933, the alleged discrepancy between the estimate Wheatcroft derives and the tabular entry vanishes. ${ }^{18}$ Hence the assertion that Urlanis published two mutually inconsistent population statistics back to back on adjoining pages cannot be objectively sustained. His phraseology may to some extent have been ambiguous, but imprecision does not warrant Wheatcroft's inference that he was confused or inept. ${ }^{19}$ If Urlanis had concluded that a simple point estimate was scientifically unjustified, he could have conveyed this straightforwardly without compromising his argument, or exposing himself to criticism for deferring to Lorimer, ${ }^{20}$ merely by replacing the population figure in his table with the bounded interval 158-161.4 million people.

Wheatcroft's second line of argument is similarly misguided. He contends that the population in 1933 was below the level estimated as late as 1937 by Gosplan because the rate of natural increase was smaller than anticipated. ${ }^{21} \mathrm{He}$

13. Urlanis, Problemy, p. 318.

14. Wheatcroft, "New Demographic Evidence."

15. Wheatcroft implicitly estimates that the Soviet population grew 0.7 million January 1,1933 to April 1, 1933 when he asserts that Urlanis's estimate of 158 million April 1, 1933 is equivalent to 157.3 on January 1 , 1933. Adding 0.7 million to the 160.7 million figure he derives from Urlanis's discussion of p. 318 yields an alternative estimate April 1, 1933 of 161.4 million people.

16. Wheatcroft loosely fixes this difference at 2.5 million.

17. Urlanis, Problemy, p. 318. Novosel'skii and Paevskii's estimates were published in 1934.

18. Urlanis's estimate for the end of 1933 is 160.7 million. If he estimated a net population increase of 2.7 million during 1933, his figure for January 1, 1933 would be 158 million as reported in the table. Observe also that the net increase need not be precisely 2.7 because both the 160.7 and 158 million figures are described as approximations. Ibid.

19. Wheatcroft cultivates this impression to justify his contention that Urlanis is merely reporting Lorimer's estimate and has no valid independent basis to compute his 1933 population estimate.

20. "But even Urlanis would not have been able to say in print that he thought the estimates of the Western bourgeois demographer Lorimer were the best approximate figures available." Wheatcroft, "New Demographic Evidence."

21. Ibid. In my article I stated that "assuming that Gosplan had access to the relevant data when this estimate was made in 1937, it appears to follow that all excess deaths calculated from the census of 1939 occurred after rather than before 1933." See Rosefielde, "Excess Collectivization Deaths," p. 83. Wheatcroft points out that the same estimate was published earlier in Sotsialisticheskoe stroitel'stvo. To be more precise, therefore, I should have substituted the words "published anew" for "made." The reader can confirm that this correction does not materially alter the meaning of my statement, although Wheatcroft tried to make it appear as if the distinction were decisive. Compare Frank Lorimer, Population of the Soviet Union: History and Prospects (Geneva: League of Nations, 1946), p. 112. 
fails to recognize, however, that this discrepancy is irrelevant to my calculations. ${ }^{22}$ Excess deaths in table 1 are computed entirely from official ex post, censuscompatible vital statistics, ${ }^{23}$ not from Gosplan's 165.7 million population estimate of 1933. If my calculations are wrong the fault can only lie in the initial and terminal population statistics for 1929 and $1933^{24}$ and in the vital rates employed for the period between 1929 and 1933. The natality rates, as previously explained, are postwar statistics for the USSR compiled by Urlanis, which differ only slightly from corresponding prewar estimates for the European part of the Soviet Union. ${ }^{25}$ It could be hypothesized that these natality rates are too high, but the evidence is wanting. The statistics for 1929 and 1930 are consistent with the 1926/27 census data, ${ }^{26}$ while the rates for 1931 and 1932 are below Lorimer's. ${ }^{27}$ Any significant exaggeration in my excess death estimates therefore must

22. Wheatcroft erroneously suggests that I compare Urlanis's statistic with Gosplan's demographic projection of 165.7 million in tables 1,2 , and 1A. Similar comments which assume that my estimates are biased by natural increase projections are likewise incorrect: "A common cause of error is to use a deflated figure for the size of the population in 1933 and a non-inflated figure for 1931" (Wheatcroft, "New Demographic Evidence"). All the population estimates in table 1 are derived from official census data, census-compatible vital statistics, and Urlanis's 1933 fakticheskii population statistic. None of these data are derived from projections.

23. Rosefielde, "Excess Collectivization Deaths," p. 84.

24. The population statistic for 1929 was computed by adding the natural increase indicated by official, published vital rates in 1927 and 1928 to the January 1, 1927 census-based population statistic. Corroboration of Urlanis's estimate has recently been provided by Ger P. van den Berg, who discovered that the population statistics used by Gertsenzon and Shliapochnikov in the 1930s differed from officially published data and imply a population of 155.1 million in 1933. (The figures for 193135 are respectively $160.5,159.5,155.1$, and 157.5 million). See Ger P. van den Berg, The Soviet System of Justice: Figures and Policy [Boston, Mass.: Martinus Nijhoff, Kluwer Academic, 1985], Demographic Data, table 1, p. 175. Van den Berg comments: "We do not know whether the population data used by Gertsenzon to calculate the number of sentences for hooliganism per 100,000 inhabitants are the correct figures, but the publication of these numbers in 1935 at least proves that Gertsenzon knew that the population figures for the years 1932-1934 were about 10 million lower than the figures published in contemporary official sources" (p. 176).

25. The postwar rates are employed because they represent an official selection of sometimes inconsistent prewar rates, because they were probably adjusted to take account of new information and because they cover the entire Soviet Union rather than the European part only. Nonetheless, they do have one drawback. They include the natality and mortality behavior of the populations annexed to the Soviet Union after September 17, 1939. On balance they should provide a superior, but not an ideal impression of prewar vital rates. The differences among the pre- and postwar rates, however, are comparatively minor and do not significantly affect the excess death estimates computed in table 1. Rosefielde, "Excess Collectivization Deaths," p. 84; Rosefielde, "Excess Mortality in the USSR 1929-49: A Rejoinder to Stephen Wheatcroft," unpublished manuscript, July 1985. Compare Wheatcroft, "A Note on Steven Rosefielde's Calculations of Excess Mortality in the USSR, 19291949," Soviet Studies, 36, no. 2 (April 1984): 280, n. 8.

26. Naselenie SSSR, p. 9; Lorimer, Population of the Soviet Union, p. 114.

27. Ibid., p. 134. Ger P. van den Berg argues persuasively that Urlanis's natality statistic for 1932 of 32.6 per thousand may be an average for the years 1931-34. He uses statistics on cohort survivors in 1972 to estimate the crude birth rate 1931-34 and obtains the following results: 1931, 35.6 per thousand; 1932, 37 per thousand; 1933, 29.2 per thousand; 1934, 29.8 per thousand. See van den Berg, Soviet System, table 2, p. 177. These alternative natality rates have little effect on total excess deaths 1929-39, but they have a profound impact on excess mortality for the period January 1, 1929 to January 1, 1933. Excess collectivization deaths increase from 5.8 million (Rosefielde, "Excess Collectivization Deaths 1929-1933," table 1, p. 84) to 7 million shown in table N1 below. 
be explained by the mortality rates. But this possibility is also implausible because the official postwar statistics employed are close to the census values and do not differ greatly from the prewar figure of 1926/27 for the European part of the Soviet Union. ${ }^{28}$ It follows directly, therefore, that if the 5.8 million excess deaths computed in table 1 have innocent explanations, the problem must repose in the census data which support the vital statistics rather than in post-census reporting deficiencies that might distort these latter rates. ${ }^{29}$

Although Wheatcroft does not acknowledge this in his present critique, his prior writings indicate that he believes most of the excess deaths implied by

Table N1. Excess Collectivization Deaths 1929-33 (van den Berg's Natality Rates 1931 and 1932)

\begin{tabular}{|c|c|c|c|c|c|}
\hline Year & $\begin{array}{c}\text { Population } \\
\text { January } 1 \\
\text { (Thousands) } \\
\text { (1) }\end{array}$ & $\begin{array}{l}\text { Births per } \\
1,000 \\
\text { Population } \\
\text { (2) }\end{array}$ & $\begin{array}{c}\text { Deaths per } \\
1,000 \\
\text { Population } \\
\text { (3) }\end{array}$ & $\begin{array}{c}\text { Births } \\
\text { (Thousands) } \\
\text { (4) }\end{array}$ & $\begin{array}{c}\text { Deaths } \\
\text { (Thousands) } \\
(5)\end{array}$ \\
\hline 1929 & 153,740 & 41.8 & {$[21.4]$} & 6,426 & 3,290 \\
\hline 1930 & 156,876 & 41.2 & [21.0] & 6,463 & 3,294 \\
\hline 1931 & 160,045 & & & & \\
\hline Discrepancy & $-6,952$ & & & & \\
\hline 1931 & 153,093 & {$[35.6]$} & [20.6] & 5,450 & 3,153 \\
\hline 1932 & 155,389 & [37.0] & [20.2] & 5,749 & 3,139 \\
\hline 1933 & 158,000 & & & & \\
\hline \multicolumn{6}{|l|}{ 1929-33 } \\
\hline \multicolumn{6}{|l|}{ Actual } \\
\hline Increase & 4,260 & & & & \\
\hline \multicolumn{6}{|l|}{ Expected } \\
\hline Births & 24,088 & & & & \\
\hline \multicolumn{6}{|l|}{ Expected } \\
\hline Deaths & 12,876 & & & & \\
\hline \multicolumn{6}{|l|}{ Births } \\
\hline \multicolumn{6}{|l|}{ Minus } \\
\hline Deaths & 11,212 & & & & \\
\hline Discrepancy & $-6,952$ & & & & \\
\hline
\end{tabular}

Data: The bracketed natality terms were computed by Ger P. van den Berg from statistics on cohort survivors in 1972; bracketed mortality statistics have been interpolated from average observed values $1927-28$ and $1937-38$. The 1933 population estimate is Urlanis's. The population figure for 1929 has been computed with official vital statistics from the 1926 census estimate.

Sources: Urlanis, "Dinamika urovnia rozhdaemosti v SSSR," in A. G. Vishnevskii, Brachnost', rozhdaemost', smertnost' v Rossii i v SSSR (Moscow, 1977), table 3, pp. 11-12; Urlanis, Problemy dinamiki naseleniia SSSR (Moscow, 1974), p. 9; Ger P. van den Berg, The Soviet System of Justice: Figures and Policy, table 2, p. 177.

Method: Estimates 1931-32 are extrapolated backward with the formula $\mathrm{P}^{\mathrm{t}-1}=\mathrm{P}^{\mathrm{t}} /(1+\alpha-\beta)$ where $\alpha$ is the birth rate and $\beta$ is the death rate in year $t-1$.

Comment: Stalin estimated the Soviet population to be 160.5 million at the end of 1930 in his report to the Seventeenth Party Congress (1934). See van den Berg, Soviet System, table 1, p. 175. This figure is very close to the estimate shown above.

28. Ibid., pp. 114 and 134.

29. Wheatcroft argues that intercensus vital statistics are more broadly unreliable than suggested here, but his reservations are not directed pointedly at the vital rates in question. See Wheatcroft, "New Demographic Evidence," and Wheatcroft, "Population Dynamic and Factors Affecting it, in the Soviet Union in the 1920s and 1930s," part 1, CREES Discussion Papers, Birmingham University, 1976, pp. 2-3. 
official Soviet demographic statistics are the fictitious consequences of an erroneously low mortality rate based on the census of 1926/27. ${ }^{30}$ Citing Lorimer, he contends that this rate is biased by the underregistration of deaths and by the underestimation of mortality in the non-European part of the USSR. This hypothesis cannot be dismissed, but the evidence supporting it is circumstantial and insufficient to sustain cardinal adjustments of any meaningful dimension. Lorimer's conjectures about underregistered deaths stem from what he deemed to be a suspicious divergence between the lifetable mortality rates of adults over 25 in the European part of the Soviet Union and Western Europe. On the basis of these suspicions he adjusts the lifetables of the $25+$ cohort, for the European part of the Soviet Union, and then with no further empirical justification similarly adjusts the 0-5 cohort; death rates outside the European part of the USSR in Buriat-Mongolia, the Far Eastern Territory, and Armenia; and he arbitrarily fixes the mortality rate in Central Asia, the Asiatic steppe region, and most of the Transcaucasus at a level 80 percent above the census rate. ${ }^{31}$

The sole empirical basis for these diverse adjustments, which yield an estimated 1926/27 mortality rate 31 percent higher than the official figure for the European part of the Soviet Union, is the allegedly suspicious mortality behavior of the $25+$ lifetable rates..$^{32}$ The suspicions, however, are not supported by standard tests of statistical significance, and Lorimer neglects to consider further whether the lifetable behavior of Western Europe provides a valid standard for judging normal, age-specific Soviet mortality, and derivatively the underregistration of deaths in the European part of the USSR. Hence his estimates are speculative and have no secure scientific foundation.

Lorimer's lapse in this regard does not, of course, preclude the possibility that evidence confirming his hypothesis may ultimately be forthcoming. Given the current state of knowledge, however, the likelihood of this outcome is slight. Soviet demographers who are aware of his work ${ }^{33}$ have shown no inclination to follow his lead. Wheatcroft, who believes that Lorimer's adjustments may not have been sufficiently bold, has failed to publish any direct substantive proof, ${ }^{34}$ while other potentially confirmatory information points compellingly in the opposite direction. If underregistration and incomplete coverage did significantly

30. Wheatcroft, "Population Dynamic and Factors Affecting it, in the Soviet Union in the 1920s and 1930s," part 2, p. 70; and Wheatcroft, "A Note on Steven Rosefielde's Calculations of Excess Mortality," pp. 178-79, and nn. 21 and 22, p. 281.

31. Lorimer, Population of the Soviet Union, pp. 115-19. Other evidence of underregistration is discussed, but it is ordinal in character and does not permit precise cardinal adjustments. The official 1926/27 mortality rate for the European part of the Soviet Union was 19.9 per thousand. The death rate for Central Asia, the Asiatic steppe region, and most of the Transcaucasus was set at 35 per thousand, in line with the rate reported for Viatka and the Ural regions in 1927, even though Lorimer acknowledges that "we have no specific information" about mortality in these regions. Compare Sergei Maksudov's critique of Lorrimer's death rate estimate in "How Many Millions Perished From 1930-1938?" Russia, nos. 7-8 (1983), pp. 10-11.

32. Lorimer estimated that the Soviet mortality rate $1926 / 27$ was 26 . The official rate for the European part of the Soviet Union was 19.9 per thousand. Also see note 30.

33. Urlanis, Problemy, p. 234.

34. Wheatcroft, "A Note," p. 181, nn. 21 and 22; and Wheatcroft, "Population Dynamic and Factors Affecting it, in the Soviet Union in the 1920s and 1930s," part 2, p. 70. 
distort the 1926/27 mortality rate, this error might have been partly revealed by an unanticipatedly high death rate based on the census of 1939. The 1938/39 mortality statistic, however, was in the vicinity of 17.5 per thousand, ${ }^{35}$ a figure compatible with a $1926 / 27$ based mortality rate of 20.3 per thousand for the Soviet Union ${ }^{36}$ and insufficiently close to Lorimer's 26 rate to sustain his hypothesis. Moreover, as indicated in table 2 and explained more fully elsewhere, the demographic record of the 1940s reveals an exorbitant number of excess fatalities unrelated to the war that cannot be attributed to innocent causes without implying absurd demographic outcomes. ${ }^{37}$ This finding suggests that excess deaths during and before the 1940s are adequately explained by real causes including collectivization, famine, the Gulag, and the terror, which should take precedence over speculative theories that attribute them to the underestimation of the 1926/27 mortality rate.

Wheatcroft may some day uncover compelling evidence that controverts my analysis. But he cannot sustain his present case on the basis of speculative induction any more than on the over-interpretation of Urlanis's allegedly contradictory population statistics for 1933, or his misunderstanding of my method for estimating excess deaths. The crux of the matter is this: Wheatcroft has no credible evidence to substantiate his assertion that Soviet demographic statistics do not support more than 3 to 4 million excess "famine" deaths and 6 million cumulative excess fatalities between 1926 and 1939. Soviet statistics demonstrate clearly that the Soviet Union sustained approximately 5 to 6 million excess fatalities related to collectivization from January 1, 1929 to January 1, 1933. ${ }^{38}$ It is also possible in view of the 1937 population statistic reported by AntonovOvseenko, broadly corroborated by my own full period excess death computations for 1929 to $1949,{ }^{39}$ that Urlanis's 1933 population statistics may be overstated by several million people, and that the 15 to 20 million excess fatalities between 1929 and 1939 estimated by Murray Feshbach are demographically supportable. These findings do not settle all outstanding points of controversy, ${ }^{40}$ but

35. Naselenie SSSR, p. 9; Lorimer, Population of the Soviet Union, p. 134.

36. Naselenie SSSR, p. 9.

37. Rosefielde, "Excess Mortality in the USSR 1929-49: A Rejoinder to Stephen Wheatcroft," p. 85 .

38. See note 27.

39. Rosefielde, "Excess Mortality in the Soviet Union: A Reconsideration of the Demographic Consequences of Forced Industrialization 1929-1949," Soviet Studies, 35, no. 3 (July 1983): 402, table 12. Antonov-Ovseenko's 1937 population estimate of 156 million is supported by the Gertsenzon statistics reported by van den Berg, especially if they are overstated as seems likely by the exclusion of sample data from the Ukraine, Kazakhstan, the North Caucasus, and the Middle Volga. See van den Berg, Soviet System, p. 177. Also observe that Gertsenzon's population estimates implausibly suggest a positive natural increase in 1933. This was a principal famine year. Any significant adjustment on this score would place the population as of January 1, 1934 in the vicinity of 152.5 million, a figure clearly compatible with Antonov-Ovseenko's 1937 census statistic.

40. Full rebuttals of Wheatcroft's prior criticisms are provided in Rosefielde, "Excess Mortality in the USSR 1929-49: A Rejoinder to Stephen Wheatcroft," and Rosefielde, "A Reassessment of the Sources and Uses of Gulag Forced Labor, 1929-56." Both manuscripts are available on request. 
they demonstrate that the demographic cost of Stalin's political and economic programs vastly exceeded the few million excess deaths attributable to official acts of violence and repression that Wheatcroft may be willing to concede. ${ }^{41}$

41. In his impassioned concluding remarks Wheatcroft attempts to seize the high ground by asserting that "it is no betrayal of [the millions who died prematurely in this period] nor an apologia for Stalin to state that there is no demographic evidence to indicate a population loss of more than six million between 1926 and 1939 or more than 3 or 4 million in the famine." This phraseology suggests that he had dispassionately considered the counter-evidence, but this is not the case. In the sentence quoted above, note that the 5 million excess deaths Feshbach and I have ascribed to collectivization have been transformed into excess famine deaths, a separate and comparatively innocent probable cause. Compare James Mace, "Famine and Nationalism in Soviet Ukraine," Problems of Communism, 33 (May-June 1984): 37-50; and Mace, "Response to Stephen Wheatcroft," Problems of Communism, 34 (March-April 1985): 134-38, where he persuasively attributes the famine to a deliberate policy of genocide in the Ukraine. Also see Sergei Maksudov, "Losses Suffered by the Population of the USSR in 1918-1958," Cahiers du monde russe et soviétique, 1977, no. 3. This formulation commits Wheatcroft to very little. As in the past, he is here prepared to accept Lorrimer's 5.5 million excess fatalities $1929-1939$ as a starting point but then goes on to imply that most are imputable to innocent causes including malaria, the hardship of peasant relocation, famine, the Soviet-Finnish War, and statistical error. Thus while he acknowledges "excesses," he is puzzlingly unprepared to admit that they could be a consequence of Stalin's political and economic policies. 